NOTE

\title{
Methods to enhance the intensity of intranuclear bacilliform virus infection in Cherax quadricarinatus
}

\author{
Kerry Claydon, Bradford Cullen, Leigh Owens* \\ Microbiology and Immunology, James Cook University, Townsville, Queensland 4811, Australia
}

\begin{abstract}
Many studies have examined the morphology, pathology and epizootiology of the intranuclear bacilliform virus (IBV) of Cherax quadricarinatus, but little research has been conducted to acquire specific knowledge of the virus. This is partly due to difficulties in detecting the virus and in obtaining sufficient material for viral isolation and purification. As quantified by light microscopy, we significantly ( $\mathrm{p}$ 0.01) enhanced IBV intensities from 10.56 to $16.67 \%$ in C. quadricarinatus by using salinity stress (12 ppt) and ingestion of infected hepatopancreatic tissue, which increased intensities from 4.33 to $10.77 \%$. It was also found that phosphotungstic acid-eosin stain was superior to standard haematoxylin and eosin stain in visualizing IBV inclusion bodies. It is expected that these new techniques will enhance the detectability of the virus and provide sufficient viral material for viral purification, characterization and development of molecular tools for detection and phylogenetic analysis.
\end{abstract}

KEY WORDS: Cherax quadricarinatus $\cdot$ Intranuclear bacilliform virus $\cdot$ Histology

\section{INTRODUCTION}

Australia has the richest fauna of freshwater crayfish in the world. Three species of Cherax are considered to have aquaculture potential (Edgerton \& Owens 1993, Austin 1995). Cherax quadricarinatus is the most widely cultured species, and is native to northern Australia and New Guinea (Edgerton \& Owens 1997). Commonly known as red claw crayfish, these animals are environmentally robust with a temperature tolerance between 10 and $30^{\circ} \mathrm{C}$, and a salinity tolerance of 0 to 12 ppt (Austin 1995), allowing for potential culture over a large geographical range.

The most widely reported pathogen of this freshwater crayfish is a virus described as an intranuclear bacilliform virus (IBV), found in the hepatopancreas. The inclusion bodies that are pathognomonic for IBV infection reside within the hepatopancreatic tubules, which in Cherax quadricarinatus has caused disease and low-grade mortalities throughout the world (Edgerton \& Owens 1993, 1997, Groff et al. 1993, Edgerton et al. 1995, Hedrick et al. 1995, Jimenez \& Romero 1998,
Romero \& Jimenez 2002). However, IBV infections have been described as low in prevalence (Groff et al. 1993, Edgerton et al. 1995, Edgerton \& Owens 1997, Jimenez \& Romero 1998) and, under proper husbandry, the disease is manageable.

No virus from freshwater crayfish has been purified to permit further characterization beyond preliminary descriptions of its morphology, pathology and epizootiology. Description of the physicochemical characteristics and the structure and function of the genome of IBV is lacking. Several well-known difficulties have inhibited further in-depth study of many crustacean viruses; the lack of established crustacean cell lines for the production of large amounts of virus, the lack of sensitive diagnostics, and the traditional methods used to isolate and obtain intact virions have proved unsatisfactory with crustaceans.

The aim of this study was to develop improved methods for detection of IBV in Cherax quadricarinatus and to test methods for increasing the intensity of viral infections to aid in viral isolation, purification and characterization. 


\section{MATERIALS AND METHODS}

Source of animals. Cherax quadricarinatus were produced at James Cook University, Townsville, and have been part of a continuous breeding population for 10 yr. The IBV-infected animals were housed completely separate and formed the bulk of the experimental crayfish. Presumptive virus free juveniles were produced from female brooders by removing the eggs at the eyed stage, sterilizing (10\% formalin) and hatching them, and culturing the juveniles in uncontaminated water (Edgerton \& Owens 1997). From this point on, the crayfish were maintained in an isolated pathogen-free area, and were occasionally examined for IBV and always found free of infection.

Histopathology. Hepatopancreatic tissues were removed, and preserved in Davidson's fixative (Humason 1967) for $24 \mathrm{~h}$, then transferred to $70 \%$ alcohol. Sections were cut at $5 \mu \mathrm{m}$ and stained with experimental staining techniques. These included Mayer's haematoxylin and eosin (H\&E) (Mayer 1903), phloxine and eosin (Carson 1990), Martius scarlet blue (MSB) (Lendrum et al. 1962), and phosphotungstic-acid eosin (Massignani \& Malferrari 1961).

To quantify the intensity of IBV infection, one area of 20 adjacent tubules was randomly selected in the proximal region of a hepatopancreatic section, and examined using a $40 \times$ magnified objective. Tubules that contained cells with IBV inclusion bodies were recorded as a percentage of the 20 tubules examined. In addition, the number of infected cells was recorded as a percentage of the total number of cells within each infected tubule.

Environmental stress experiments. Eight glass aquaria $(60 \times 60 \times 30 \mathrm{~cm})$ were set up to conduct experiments with environmental stressors. The effect of optimal rearing conditions was compared to stressful water quality parameters of salinity (12 ppt), pH (6.0 to 6.5) and temperature $\left(32^{\circ} \mathrm{C}\right)$. Tanks were adjusted to the environmental stress condition before the addition of crayfish at a density of 5 individuals per tank. Two size groups of crayfish (2 to 3 and 6 to $8 \mathrm{~cm}$ total length) were examined. All crayfish used in this experiment were from stocks known to have carriers of IBV. Replicates of 2 tanks for each treatment were established along with a control tank for each size group.

Water conditions for the control tanks and the feeding experiments were held at optimal levels for Cherax quadricarinatus (Austin 1995), with the combined parameters of salinity (0 ppt), $\mathrm{pH}$ (7.6) and temperature $\left(26^{\circ} \mathrm{C}\right)$. At the end of the experiment (35 d), animals were sacrificed and the hepatopancreas removed. One half of the tissue was frozen at $-20^{\circ} \mathrm{C}$ for use in feeding experiments, and the other half was examined by microscopy after histological staining.
Feeding experiments. For feeding experiments, 3 replicates for each experimental group were conducted over $13 \mathrm{~d}$. Group 1 was the control group of Cherax quadricarinatus known to carry IBV and fed a normal pelleted diet (Ridley stockfoods). Group 2 was C. quadricarinatus known to be carrying IBV but fed IBV-infected hepatopancreatic tissue stored from the environmental stress experiments. Group 3 comprised putative viral-free C. quadricarinatus (Edgerton \& Owens 1997) that were also fed infected hepatopancreatic tissue. Crayfish size was approximately $5 \mathrm{~cm}$ total length. The experiment was initiated by $3 \mathrm{~d}$ of starvation before Groups 2 and 3 were fed hepatopancreatic tissue from 30 infected crayfish for $3 \mathrm{~d}$, followed by pelleted diet for $7 \mathrm{~d}$. Group 1 was fed pelleted feed for all $10 \mathrm{~d}$. At the end of the experimental period, crayfish were sacrificed and the hepatopancreas was removed and examined by light microscopy for IBV inclusions.

Statistical analysis. Data were statistically analyzed by univariate analysis of variance (ANOVA). Since the data were not normally distributed as seen by Q-Q plots, linear values were achieved by transforming data to $\log 10$. When ANOVA tests showed significant differences at $\mathrm{p} \leq 0.05$, comparisons between individual means was performed using least significant difference (LSD).

\section{RESULTS AND DISCUSSION}

\section{Histopathology}

The experimental crayfish showed histopathological lesions similar to those previously reported for IBV in Cherax quadricarinatus (Anderson \& Prior 1992, Groff et al. 1993, Edgerton et al. 1995, Hedrick et al. 1995, Edgerton 1996a,b, Edgerton \& Owens 1997, 1999, Jimenez \& Romero 1998, Hauck et al. 2001, Romero \& Jimenez 2002). These occurred throughout the medial and proximal hepatopancreas and contained cells with markedly hypertrophic nuclei. With phosphotungsticacid eosin stain (Fig. 1), affected nuclei showed central, finely granular eosinophilic inclusions and marginated chromatin, often accompanied by a laterally displaced nucleolus that gave them a characteristic 'signet ring' appearance.

\section{Staining techniques}

Of the 4 staining methods tested, phosphotungsticacid eosin provided the best visual distinction between hypertrophic nuclei containing IBV inclusion bodies and normal uninfected cells (Figs. 2 to 5). Colourless 


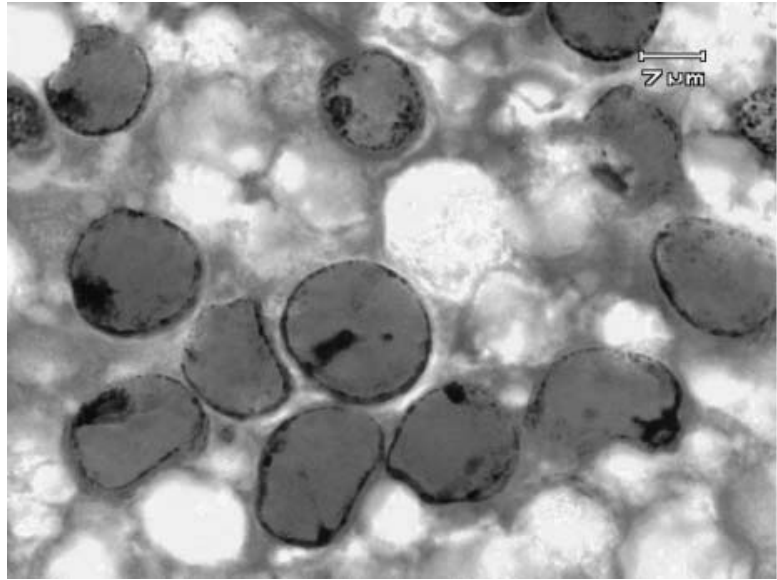

Fig. 1. Light micrograph of an intranuclear bacilliform virus (IBV) lesion in Cherax quadricarinatus. Infected nuclei are markedly hypertrophic with an eosinophilic center, marginated chromatin and peripherally displaced nucleoli, giving them a characteristic 'signet ring' appearance. Phosphotungstic-acid eosin stain. Scale bar $=7 \mu \mathrm{m}$ phosphotungstic-acid is able to enter most tissue pores, except for those with fine porosity such as viral inclusions and red blood cells (Bancroft \& Cook 1984). Therefore, the eosin staining IBV inclusion bodies were easily distinguishable from a paler background. Phloxine and eosin and MSB were the next most useful for IBV visualization, largely due to their ability to colour differentiate between cellular structures (Bancroft \& Stevens 1977, Bancroft \& Cook 1984) and allow viral inclusions to be more easily distinguished. The least effective stain was H\&E, even though it is the conventional method used for histological screening (Bancroft \& Cook 1984).

\section{Environmental stress experiments}

Histological analysis of the number of viral inclusion bodies revealed that salinity stress was the most effective method to significantly $(F=3.985$, df $=3,72$,

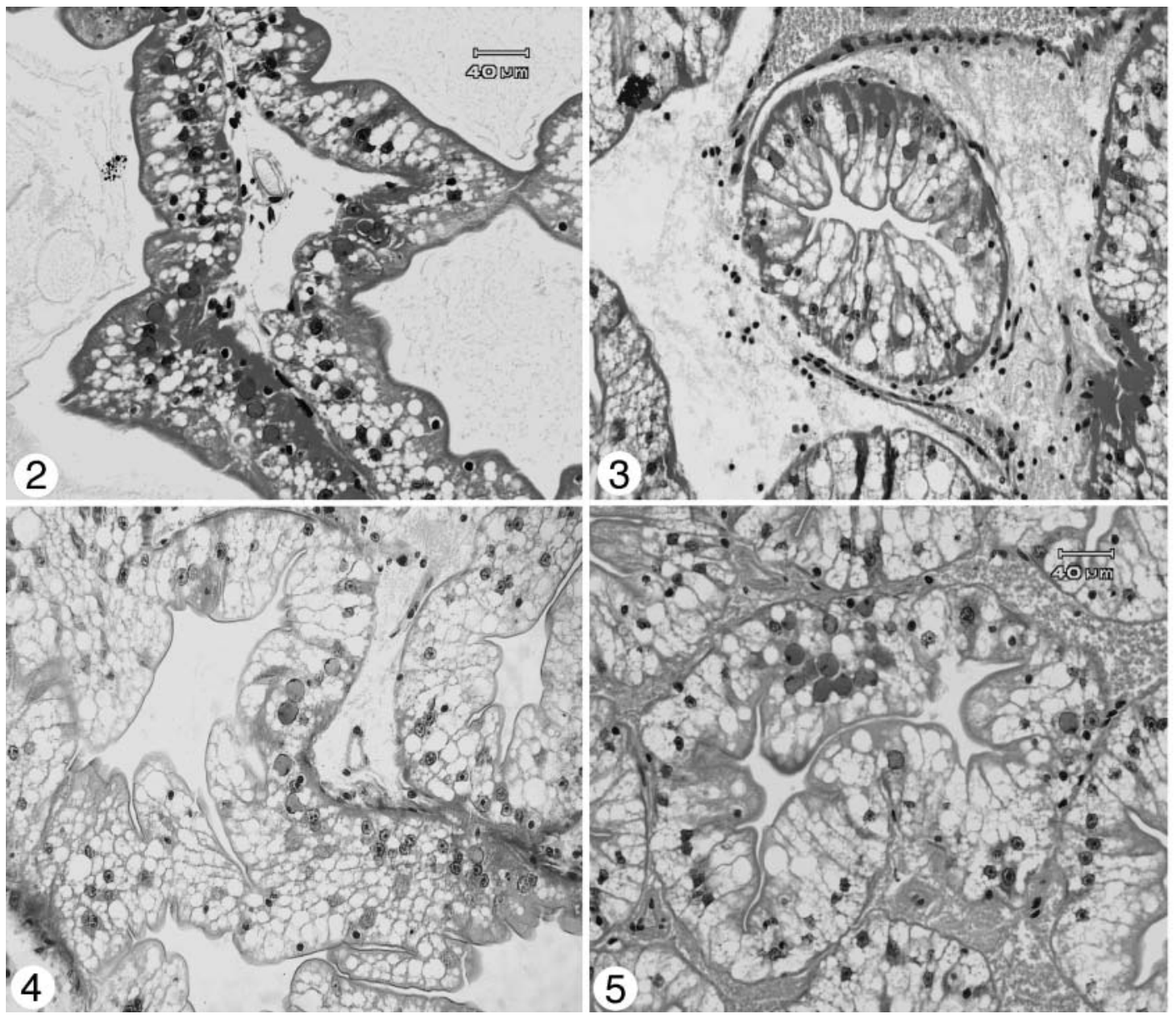

Figs. 2-5. Comparison of 4 staining methods for visualization of IBV inclusion bodies in Cherax quadricarinatus hepatopancreatic tubules. Fig. 2. Mayer's haematoxylin and eosin (H\&E) stain. Fig. 3. Phloxine and eosin. Fig. 4. Martius scarlet blue. Fig. 5. Phosphotungstic-acid eosin. Scale bars $=40 \mu \mathrm{m}$ 
Table 1. Mean prevalence (\%) levels of tubules and cells infected, and their $95 \%$ confidence intervals (CI) for the environmental stress and feeding experiments. Group 1: control group of Cherax quadricarinatus known to carry IBV and fed a normal diet; Group 2: C. quadricarinatus known to carry IBV but fed IBV-infected HP; Group 3: putative viral-free C. quadricarinatus fed infected HP

\begin{tabular}{|lrccc|}
\hline \multirow{2}{*}{ Expt } & \multicolumn{2}{c}{ Tubules infected } & \multicolumn{2}{c|}{ Cells infected } \\
& Mean & $95 \%$ CI & Mean & $95 \%$ CI \\
\hline Stress & & & & \\
Environmental control & 10.56 & $3.8-17.32$ & 4.72 & $2.01-7.43$ \\
Increased salinity & 16.67 & $8.52-24.82$ & 8.36 & $3.19-13.53$ \\
Lowered pH & 9.29 & $4.21-14.37$ & 5.10 & $1.4-8.8$ \\
Increased temperature & 4.29 & $1.1-7.48$ & 3.77 & $0-7.58$ \\
Feeding & & & & \\
Group 1 & 4.33 & $0-9.2$ & 3.44 & $0.87-6.01$ \\
Group 2 & 10.77 & $2.7-18.84$ & 4.78 & $2.48-7.08$ \\
Group 3 & 0.00 & $0-0$ & 0.00 & $0-0$ \\
\hline
\end{tabular}

effects (Edgerton et al. 2002). Since salinity stress over $35 \mathrm{~d}$ significantly increased the prevalence of infected cells in previously infected tubules, it is possible that a longer stress period might cause the infection to spread to other previously uninfected tubules.

\section{Feeding experiment}

Despite being fed IBV-infected hepatopancrei, all crayfish in Group 3 had no IBV inclusions. In IBV-infected Groups 1 and 2, viral inclusion bodies were seen with a strong focal distribution, as described above. Heaviest infections were observed with IBV-infected Group 2 that $\mathrm{p}<0.01$ ) increase intensity. When stressed, prevalence was $16.7 \%$ compared to $10.7 \%$ in the control crayfish (Table 1, Fig. 6). Since there was no significant difference for percentage of infected tubules, it appeared that salinity stress increased viral replication within already infected tubules but did not cause new infections within previously uninfected tubules. There were no significant differences for $\mathrm{pH}$ stress, temperature stress or for crayfish size $(F=0.064, \mathrm{df}=1,72, \mathrm{p}>0.05)$.

Environmental factors are important in affecting the ability of crayfish to resist infection (Evans \& Edgerton 2001). Previous research has demonstrated that IBV causes focal lesions in Cherax quadricarinatus (Anderson \& Prior 1992, Groff et al. 1993, Edgerton 1996a, Edgerton \& Owens 1997) and that a low prevalence in this tissue does not result in observable, detrimental

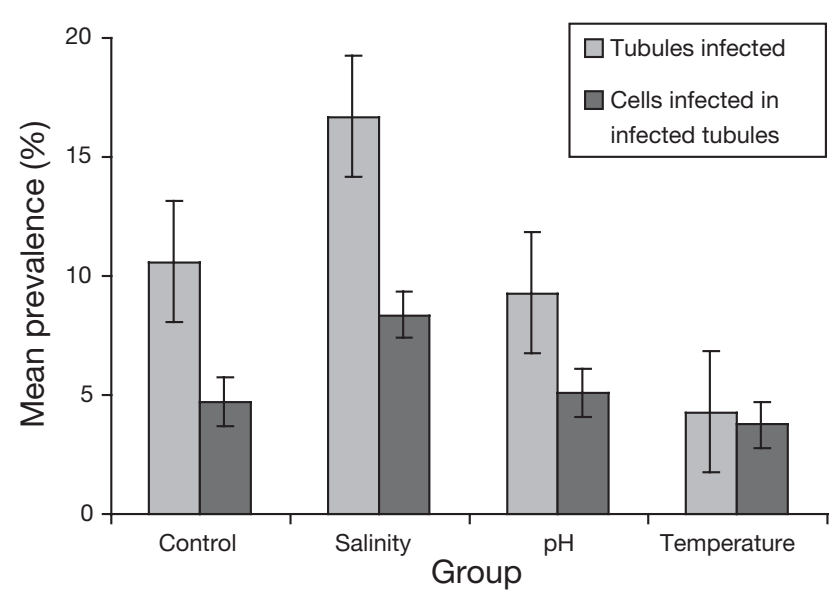

Fig. 6. Mean prevalence of IBV infection in hepatopancreatic tubules and in hepatopancreatic tubule cells of crayfish Cherax quadricarinatus exposed to environmental stress. Number of tubules infected was significantly greater in the salinity stressed animals was fed IBV-infected hepatopancreatic tissue. Both the percentage of infected tubules $(F=11.79$, df $=2,42, \mathrm{p}<$ $0.001)$ and the percentage of infected cells $(F=2.125$, $\mathrm{df}=25,68, \mathrm{p}<0.05)$ were significantly different from those for IBV-infected Group 1 fed normal pellets and IBV-free Group 3 (Table 1, Fig. 7). One crayfish in Group 2 showed $50 \%$ prevalence of IBV inclusion bodies in its hepatopancreatic tubules.

Feeding the crayfish IBV-infected hepatopancreatic tissue successfully increased the prevalence of IBV inclusions throughout the hepatopancreas in both tubules and cells of the group already infected with

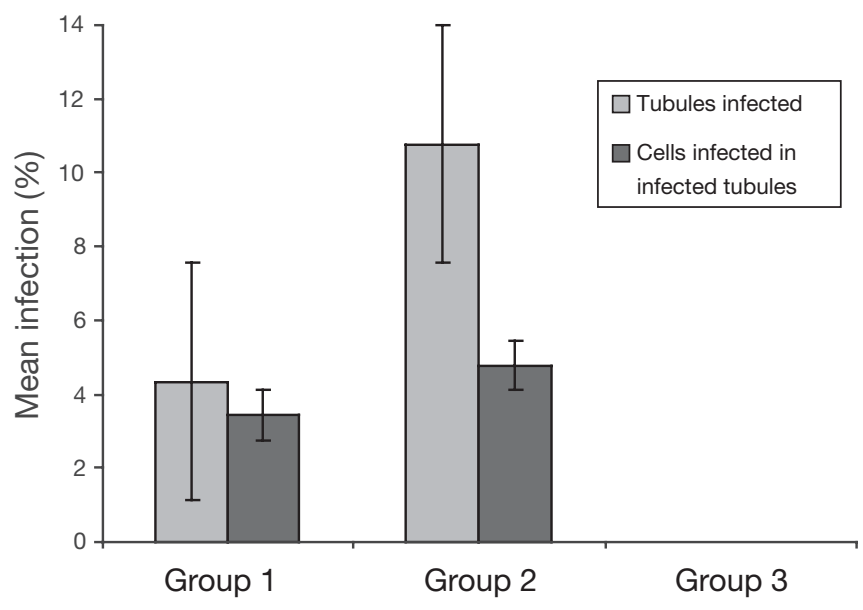

Fig. 7. Mean prevalence of viral infection in hepatopancreatic tubules and hepatopancreatic tubule cells for the feeding experiment. IBV carriers fed infected hepatopancreatic tissue (HP) had significantly higher viral levels. No viral infection was observed in putative viral-free crayfish. Group 1: control group of Cherax quadricarinatus known to carry IBV and fed a normal diet; Group 2: C. quadricarinatus known to carry IBV but fed IBV-infected HP; Group 3: putative viral-free C. quadricarinatus fed infected HP 
IBV. This supports the notion that Cherax quadricarinatus acquires IBV per os (Edgerton \& Owens 1997). IBV from digestive systems of other crustaceans are also transmitted horizontally (Johnson 1977, Pappalardo et al. 1986, Johnson \& Lightner 1988, Anderson \& Prior 1992, Flegel et al. 1995, Chang et al. 1998). Washing and sterilization of eggs and larvae are utilized to manage gastrointestinal IBV in aquaculture hatcheries (Evans \& Edgerton 2001).

Given indications of successful horizontal transmission of IBV, it was curious that no IBV inclusions were seen in the Group 3 crayfish (Edgerton \& Owens 1997). This result might signify resistance to IBV infection. Cherax quadricarinatus is known to display high levels of inter-population variability as demonstrated by allozymes, morphology, life-histories and juvenile growth rate studies (Austin 1995). Thus, it is possible that differences in physiological traits such as disease resistance may also exist. Limited research has been conducted into the disease susceptibility of virus-free progeny and this may be an area of further development.

Due to the ethical constraints on using animals in experiments, small sample sizes are manditory for experiments that result in mortality or sacrifice. This leads to the increased possibility of type I errors occurring wherein the means are statistically significantly different but in fact no real biological difference exists. To be able to assess this possibility, the 95\% confidence intervals of the means has been added to Table 1. Only further experimentation will validate these results.

In summary, our results indicate that salinity stress and feeding of IBV-infected hepatopancreatic tissue can enhance IBV infections in Cherax quadricarinatus and that the process can most easily be monitored by histological analysis using phosphotungstic-acid eosin stain. It is possible that combining these treatments and extending their time will further enhance the infections. The current lack of molecular diagnostic tools for IBV preclude more sensitive monitoring of viral levels that would be required to more accurately determine infection status of experimental animals and the results of challenge tests. These methods should allow for higher loads of IBV in crayfish that will produce enough virus for further molecular characterization.

\section{LITERATURE CITED}

Anderson I, Prior H (1992) Baculovirus infections in the mud crab Scylla serrata and a freshwater crayfish Cherax quadricarinatus from Australia. J Invertebr Pathol 60: 265-273

Austin CM (1995) Effect of temperature and salinity on the survival and growth of juvenile redclaw (Cherax quadricarinatus). Freshw Crayfish 10:419-426
Bancroft JD, Cook HC (1984) Manual of histological techniques, Churchill Livingstone, London

Bancroft JD, Stevens A (eds) (1977) Theory and practice of histological techniques, Churchill Livingstone, London

Carson FL (1990) Histotechnology: a self-instructional text. American Society of Clinical Pathologists (ASCP) Press, Chicago

Chang PS, Chen LJ, Wang YC (1998) The effect of ultravoilet irradiation, heat, $\mathrm{pH}$, ozone, salinity and chemical disinfectants on the infectivity of white spot syndrome baculovirus. Aquaculture 166:1-17

Edgerton B (1996a) Viruses of freshwater crayfish. PhD thesis, James Cook University, Townsville

Edgerton B (1996b) A new bacilliform virus in Australian Cherax destructor (Decapoda: Parastacidae) with notes on Cherax quadricarinatus bacilliform virus (=Cherax baculovirus). Dis Aquat Org 27:43-52

Edgerton B, Owens L (1993) Diseases relevant to crustacean aquaculture in tropical Australia. In: Osbourne $\mathrm{H}$ (ed) Vet update 93. University of Queensland, Brisbane, p B14-B36

Edgerton B, Owens L (1997) Age at first infection of Cherax quadricarinatus by Cherax quadricarinatus bacilliform virus and Cherax giardiavirus-like virus, and production of putative virus-free crayfish. Aquaculture 152:1-12

Edgerton BF, Owens L (1999) Histopathological surveys of the redclaw freshwater crayfish, Cherax quadricarinatus, in Australia. Aquaculture 180:23-40

Edgerton B, Owens L, Harris L, Thomas A, Wingfield M (1995) A health survey of farmed redclaw crayfish, Cherax quadricarinatus (von Martens), in tropical Australia. Freshw Crayfish 10:322-338

Edgerton B, Evans L, Stephens F, Overstreet R (2002) Synopsis of freshwater crayfish diseases and commensal organisms. Aquaculture 206:57-135

Evans LH, Edgerton BF (2001) Pathogens, parasites and commensals. In: Holdich DM (ed) Biology of freshwater crayfish. Blackwell Science, London, p 377-438

Flegel T, Fegan D, Srinrairatan J (1995) Environmental control of infectious disease in Thailand. In: Hopkins JS (ed) Swimming through troubled water precedings of the special sessions of shrimp farming. World Aquaculture Society, Baton Rouge, LA, p 65-79

Groff JM, McDowell T, Friedman CS, Hedrick RP (1993) Detection of a nonoccluded baculovirus in the freshwater crayfish Cherax quadricarinatus in North America. J Aquat Anim Health 5:275-279

Hauck AK, Marshall MR, Joseph KK, Russell AL (2001) A new finding and range extension of bacilliform virus in the freshwater red claw crayfish in Utah, USA. J Aquat Anim Health 13:158-162

Hedrick RP, McDowell T, Friedman CS (1995) Baculovirus found in two species of crayfish from California. Aquaculture 95:135

Humason GL (1967) Animal tissue techniques WH Freeman, San Francisco

Jimenez R, Romero X (1998) Cherax Baculovirus (CBV) in red claw crayfish, Cherax quadricarinatus (Von Martens) cultured in Ecuador. Aquacult Res 28:923-929

Johnson PT (1977) A baculovirus from the blue crab, Callinectes sapidus: histopathology and differential diagnosis. J Invertebr Pathol 29:201-209

Johnson PT, Lightner D (1988) Rod shaped nuclear viruses of crustaceans: gut-infecting species. Dis Aquat Org 5: $123-141$

Lendrum AC, Fraser DS, Slidders W, Henderson R (1962) Studies on the character and staining in fibrin. J Clin 
Pathol 15:401-413

Massignani AM, Malferrari R (1961) Phosphotungstic-eosin combined with hematoxylin as a stain for Negri bodies in paraffin sections. Stain Technol 36:5-8

Mayer P (1903) Notiz über Haematein und Hamalaum. Z Wiss Mikrosk Mikrosk Tech 20:409

Pappalardo R, Mari J, Bonami J (1986) Tau virus infection of

Editorial responsibility: Timothy Flegel,

Bangkok, Thailand
Carcinus mediterraneous: histology, cytopathology, and experimental transmission of the disease. J Invertebr Pathol 47:361-368

Romero X, Jimenez R (2002) Histopathological survey of diseases and pathogens present in redclaw crayfish, Cherax quadricarinatus (Von Martens), cultured in Ecuador. J Fish Dis 25:653-667

Submitted: September 29, 2003; Accepted: May 29, 2004 Proofs received from author(s): July 14, 2004 